\title{
ETHANOL RECOVERY FROM LOW-CONCENTRATION AQUEOUS SOLUTIONS USING MEMBRANE CONTACTORS WITH IONIC LIQUIDS
}

\section{ODZYSKIWANIE ETANOLU Z NISKOSTEŻ̇ONYCH ROZTWORÓW WODNYCH Z UŻYCIEM KONTAKTORÓW MEMBRANOWYCH I CIECZY JONOWEJ}

\begin{abstract}
Recovery of alcohols from diluted aqueous solutions is highly energy-intensive. In order to reduce the costs of concentration of alcohols, membrane processes (including membrane extraction) are used. This paper reports the results of ethanol concentration from diluted aqueous solutions using a hollow fiber membrane contactor with ionic liquid. The studies were performed using a contactor with microporous hollow fiber membranes. The membrane creates a barrier between the feed and extracting solvent, also providing a large mass transfer area. In the process, selected ionic liquid presenting different selectivity towards ethanol was used as extractant. The experiments were performed with feed concentrations of ethanol ranging from 1 to 5 wt. $\%$ and various feed flow rates ranging from 1 to $8 \mathrm{dm}^{3} / \mathrm{h}$.
\end{abstract}

Keywords: membrane contactor, ionic liquid, membrane extraction

\section{Introduction}

Alcohol recovery from diluted aqueous solutions is highly energy-intensive; therefore, new methods and devices are being investigated, often involving innovative technologies, to improve its efficiency. New concepts postulate using mass exchangers providing larger transfer areas than those of the conventionally applied equipment. Thus, both the space necessary for such device and energy requirements would be considerably reduced. Extraction efficiency may be improved, inter alia, by using more selective extracting agents. In this paper, the hollow fiber membrane contactor with application of ionic liquid as extractant is being researched. It is expected that combining unique properties of ionic liquids with the compact contactor module could improve the efficiency of extraction process.

Membrane contactors (MCs) are used for mass transfer in liquid/liquid or gas/liquid systems without dispersing one phase in the other. The key element of a contactor is a membrane enclosed in the casing. There are many types of membrane contactors, which

\footnotetext{
${ }^{1}$ Faculty of Process and Environmental Engineering, Lodz University of Technology, ul. Wólczańska 213, 90-924 Lodz, Poland, phone +48 4263137 92, email: karina.snochowska@gmail.com

*Corresponding author: karina.snochowska@gmail.com
} 
differ with regard to their structure and liquid flow direction. Depending on the liquid flow direction, membrane contactors are offered in co-current, cross-flow, or counter-current configurations. Moreover, membrane contactors may differ regarding the type and geometry of the membrane used. Both flat and hollow fiber membranes are available [1]. Depending on the process, polymeric or ceramic membranes may be applied. The type of material determines physical and chemical characteristics of the membrane, wettability, geometry, pore diameter, as well as porosity. Usually, porous membranes with pore diameters between $0.05 \mu \mathrm{m}$ and $1 \mu \mathrm{m}$ are used [2-5]. Hydrophobic porous polymeric membranes are the most popular because of their high porosity, wide availability, and low cost. Table 1 lists the most common polymers used for the production of porous membranes [6]. Ceramic membranes, which are far more thermally resistant than polymeric membranes, are also frequently utilized as contactors. They may be both hydrophilic and hydrophobic.

Materials most often used for membrane production [6]

\begin{tabular}{|c|c|c|c|}
\hline Material & Symbol & $\begin{array}{c}\text { Internal/External } \\
\text { diameter }[\boldsymbol{\mu m}]\end{array}$ & $\begin{array}{c}\text { Porosity } \\
{[\%]}\end{array}$ \\
\hline Polytetrafluoroethylene & PTFE & $1000 / 2000$ & 0.50 \\
\hline Polytetrafluoroethylene & PTFE & $1000 / 1700$ & 0.40 \\
\hline Polyethylene & PE & $482 / 706$ & 0.82 \\
\hline Polypropylene & PP & $600 / 1000$ & 0.79 \\
\hline Polypropylene & PP & $270 / 300$ & 0.30 \\
\hline Polypropylene & PP & $244 / 300$ & 0.35 \\
\hline Polyvinylidene fluoride & PVDF & $300 / 514$ & 0.7 \\
\hline Polysulfone & PS & $200 / 400$ & - \\
\hline Polyethersulfone & PES & $460 / 850$ & - \\
\hline
\end{tabular}

Table 2

Membrane contactors and the respective conventional mass exchangers [11]

\begin{tabular}{|c|c|c|c|}
\hline Conventional exchanger & New membrane module & Phase & $\begin{array}{c}\text { Driving force in the } \\
\text { process with membrane } \\
\text { contactor }\end{array}$ \\
\hline Packed and bubble columns & membrane scrubbers & $\begin{array}{c}\text { gas/liquid or liquid/ } \\
\text { liquid }\end{array}$ & concentration gradient \\
\hline $\begin{array}{c}\text { Packed columns, mixer- } \\
\text { settlers, centrifugal devices }\end{array}$ & membrane extractors & $\begin{array}{c}\text { gas /liquid or } \\
\text { liquid/liquid }\end{array}$ & concentration gradient \\
\hline $\begin{array}{c}\text { Packed and bubble columns, } \\
\text { mixer-settlers, centrifugal } \\
\text { devices }\end{array}$ & $\begin{array}{c}\text { Supported Liquid } \\
\text { Membranes (SLM) }\end{array}$ & liquid/liquid & $\begin{array}{c}\text { partial pressure / } \\
\text { concentration gradient }\end{array}$ \\
\hline $\begin{array}{c}\text { Distillation columns } \\
\text { distillation }\end{array}$ & $\begin{array}{c}\text { membrane and osmotic } \\
\text { partial pressure gradient }\end{array}$ \\
\hline High pressure homogenizers & membrane emulsifiers & liquid/liquid & pressure gradient \\
\hline Chemical reactors & phase transfer catalysis & liquid/liquid & concentration gradient \\
\hline
\end{tabular}

In a membrane contactor with the hollow fiber membrane, one liquid flows through the hollow fiber, the other flows on the outside. Mass transfer between the phases occurs through the membrane pores. The membrane serves as a barrier between phases, which ensures independent relative flow of liquid streams and prevents problems such as foaming or entrainment (typical in conventional mass exchangers). The use of a porous membrane provides a high mass transfer area relative to the device volume, which means that the 
device size is reduced and process is still efficient. Since membrane contactors are built of modules they are easy to scale up, maintain and repair [7-10]. Currently, there are several types of membrane contactors available for commercial use, which have replaced conventional equipment, including membrane scrubbers, distillers (used for osmotic distillation), extractors, emulsifiers, Supported Liquid Membranes (SLMs), and many others. Table 2 shows examples of membrane contactors that are being used and their respective conventional counterparts [11].

Currently, studies are being conducted into new applications of membrane contactors. The use of ionic liquids in membrane contactors is a novel concept.

Ionic liquids (ILs) are organic salts, normally with low melting points (below $100^{\circ} \mathrm{C}$ ). ILs with melting points below $20^{\circ} \mathrm{C}$ are called room temperature ILs (RTILs) and comprise organic cations and organic or inorganic anions. Physical and chemical properties of ILs are influenced by their structure; hence, by changing the length of the cation chain or changing the anion type ILs of different qualities can be obtained. The available number of cation/anion combinations is estimated at $10^{18}$, which allows the researchers to design an IL possessing desired properties. Low vapour pressure (close to zero), thermal stability, and ability to dissolve both organic and inorganic compounds are the key properties that make ILs perfect solvents in many membrane processes. ILs are generally non-flammable, thermally stable and selective, which in most cases further broadens the range of their possible applications. They can also be quite easily recycled after regeneration, which is most commonly done by distillation. These features make ILs an attractive alternative to the conventional volatile organic solvents (VOCs) [12-14].

Great attention is paid to the processes where ILs can be used as azeotrope breakers. Besides, the most promising applications of ILs include extractive distillation, liquid-liquid extraction and processes exploiting SLMs (Supported Liquid Membranes) [15].

The aim of extractive distillation is to remove one component of the mixture by addition of another component (so-called entrainer). The entrainer interacts with other components by changing their relative volatilities. The method is commonly used in separation of azeotropic and close-boiling mixtures, but it requires vaporization of both streams (the entrainer and component stream). The new concept consists in using ionic liquids as the entrainers. This modification allows avoiding azeotropic distillation [15].

Meindersma et al [16] investigated 1-ethyl-3-methylimidazolium dicyanamide $\left([\mathrm{EMIM}]\left[\mathrm{N}(\mathrm{CN})_{2}\right]\right)$ in order to separate ethanol-water mixtures by extractive distillation and compared the results with those obtained when using ethylene glycol as the solvent. When the ionic liquid was used (and heat integration implemented) the process required $16 \%$ less energy than when ethylene glycol was used as the entrainer.

Supported Liquid Membranes (SLMs) are porous membranes impregnated with liquids. They can be applied to many separation processes. Usually, use of conventional SLMs is associated with two common problems. The first one is vaporization of the liquid into the atmosphere or its dissolution in the contacting phase. The second one is the limited capacity of SLMs. However, it seems that favorable properties of ionic liquids can lessen these problems. For example, ILs are non-volatile, which helps minimize their losses through vaporization. SLMs containing immobilized ionic liquids are also called Supported Ionic Liquid Membranes (SILMs). SILMs are being widely studied for use in many industrial processes, $e g$ removal of acid gases from the exhaust gases generated during combustion of 
fossil fuels (eg coal). In a SILM, ionic liquid acts as a transmembrane medium that facilitates selective transportation of the separated components [12-15].

Initially ionic liquids in membrane contactors dealt with the absorption of components from exhaust gases. Albo et al [17] investigated absorption of flue gases $\left(\mathrm{CO}_{2}\right.$ and $\left.\mathrm{SO}_{2}\right)$ produced as a result of coal combustion using a hollow fiber membrane contactor with polypropylene hydrophobic hollow fiber membrane and 1-ethyl-3-methylimidazolium ethyl sulfate $\left([\mathrm{EMIM}]\left[\mathrm{EtSO}_{4}\right]\right)$. In the experiments, gas stream flowed outside the contactor membrane while the absorption liquid, ie ionic liquid, flowed inside the membrane. It was shown that the ionic liquid could replace other conventional volatile solvents as the absorption medium.

Luis et al [18] used a hydrophilic $\mathrm{Al}_{2} \mathrm{O}_{3}$ ceramic membrane to compare results with those of Albo's [17]. The studies were conducted using a polymeric membrane, with an ionic liquid flowing inside the hollow fiber membrane and gas flowing on the outside. The use of $[\mathrm{EMIM}]\left[\mathrm{EtSO}_{4}\right]$ was compared with the use of conventionally applied solvent (N,N-dimethylaniline). In this case, the results were slightly worse for the ceramic membrane and IL; however, it must be remembered that replacing the volatile solvent with IL helped reduce the costs due to the regeneration process of IL exhibiting negligible vapor pressure.

Better results concerning $\mathrm{CO}_{2}$ absorption were obtained with a polymeric membrane due to its hydrophobic nature. Moreover, polymeric membranes have been very popular as they are readily available and cheaper than ceramic membranes [17-18].

The use of ILs in membrane contactors offers advantages also for the petrochemical industry. The separation of propylene/propane mixture, due to similar physical and chemical properties of the two substances, is complicated. Currently, the mixture is separated by low-temperature distillation, which is very cost-intensive. Won et al [19] have shown that $\mathrm{Ag}^{+}$ions may reversibly complex with olefins. For that reason, separation of the mixture was investigated using propylene absorption with 1-butyl-3-methylimidazolium tetrafluoroborate $\left([\mathrm{BMIM}]\left[\mathrm{BF}_{4}\right]\right)$ and $\mathrm{Ag}^{+}$complexes. The studies were performed in a membrane contactor and semi-batch stirred tank reactor. The influence of various process parameters such as solvent type (IL or aqueous solution of $\mathrm{Ag}^{+}$complexes), composition of the feed gas, and concentration of silver salts were also researched. The positive impact of $\mathrm{IL}$ and $\mathrm{Ag}^{+}$complexes on the process efficiency was confirmed. The absorption was more efficient due to a higher contact surface area. The research and optimization showed that propylene absorption using ILs and the membrane contactor improved the efficiency of the process [20].

There are a growing number of processes leading to the production of biofuels or fuel additives. One of the main problems of biofuel industry is the separation of close-boiling or azeotropic mixtures. Separation by simple distillation is usually inefficient because of high energy consumption. Pereiro and Rodriguez [21] performed the experiments on separation of the heptane-ethanol mixture in an extraction column, packed with Raschig rings. 1-butyl-3-methylimidazolium methyl sulfate ([BMIM] $\left[\mathrm{MeSO}_{4}\right]$ ) was used as the azeotrope breaker. The obtained results confirmed that the ionic liquid was able to separate azeotropic heptane-ethanol mixtures.

In another study, Pereiro and Rodriguez [22] compared the extraction efficiency with results obtained when using 1,3-dimethylimidazolium methyl sulfate ([MMIM][MeSO$\left.{ }_{4}\right]$ ) as the solvent. Experiments were also performed in an extraction column packed with Raschig 
rings. The efficiency of $[\mathrm{MMIM}]\left[\mathrm{MeSO}_{4}\right]$ was better than that of $[\mathrm{BMIM}]\left[\mathrm{MeSO}_{4}\right]$. However, the authors indicated that both ILs were able to remove ethanol from the ethanol-heptane azeotropic mixture.

Calvar et al [23] investigated isobaric ternary vapor-liquid equilibria in the ethanol - water - ionic liquid system. In the study, 1-butyl-3-methylimidazolium methyl sulfate ([BMIM] $\left[\mathrm{MeSO}_{4}\right]$ ) was used. The experiments were performed with different amounts of the ionic liquid (solvent to feed ratio) at constant pressure. The results showed that the addition of [BMIM] $\left[\mathrm{MeSO}_{4}\right]$ to the binary ethanol - water azeotropic mixture helps break the azeotrope and dehydrate ethanol.

A growing interest is observed in processing of biomass into fuels and chemicals through bioconversion. The most attractive processes are ABE (acetone - butanol - ethanol) and ethanol fermentations. Both ethanol and n-butanol are popular chemicals suitable for numerous applications. They have also been widely studied as fuel additives. Table 3 compares butanol and ethanol with other fuels. As can be seen from the table, properties of butanol are similar to those of gasoline [24, 25].

Table 3

Properties of fuels [26]

\begin{tabular}{|c|c|c|c|c|}
\hline Fuel & $\begin{array}{c}\text { Combustion } \\
\text { energy } \\
{\left[\mathbf{M J} / \mathbf{d m}^{\mathbf{3}}\right]}\end{array}$ & $\begin{array}{c}\text { Heat } \\
\text { of vaporization } \\
{[\mathbf{M J} / \mathbf{k g}]}\end{array}$ & $\begin{array}{c}\text { RON } \\
\text { Research Octane } \\
\text { Number }\end{array}$ & $\begin{array}{c}\text { MON } \\
\text { Motor Octane } \\
\text { Number }\end{array}$ \\
\hline Gasoline & 32.0 & 0.36 & $91-99$ & $81-89$ \\
\hline Methanol & 16.0 & 1.20 & 136 & 104 \\
\hline Ethanol & 19.6 & 0.92 & 129 & 102 \\
\hline Butanol & 29.2 & 0.43 & 96 & 78 \\
\hline
\end{tabular}

At present, the separation of components from the ABE fermentation broth is highly energy-intensive. Ordinary distillation is economically unjustified. Moreover, the concentrations of ethanol and butanol in the broth are considerably low. According to available studies, extraction and pervaporation are the most promising techniques of product recovery.

Traditional solvents used in extraction (eg oleyl alcohol, mixtures of oleyl alcohol and decanol, glyceryl tributyrate), having high distribution coefficients for ethanol and butanol, may be classified as volatile organic compounds (VOCs). These solvents must be evaporated after extraction, which on one hand increases the energy demand and on the other hand poses a threat to the environment [27].

Domanska and Krolikowski [28] analyzed the extraction of butanol from aqueous solutions using different ionic liquids, namely: 1-hexyl-3-methylimidazolium tetracyanoborate ([HMIM][TCB]), trihexyltetradecylphosphonium tetracyanoborate ([DMIM][TCB] $)$ and trihexyl(tetradecyl)phosphonium tetracyanoborate $\left(\left[\mathrm{P}_{14,6,6,6}\right][\mathrm{TCB}]\right)$. Selectivities of the ionic liquids, distribution ratios, solubilities of water and alkyl chain lengths were discussed. The experiments were performed at the typical fermentation temperature $T=308.15 \mathrm{~K}$. The imidazolium-based ionic liquid was less hydrophobic than the phosphonium-based ionic liquid. The measured selectivities and distribution ratios showed that the extraction of butanol from aqueous solutions is feasible, especially when using $\left[\mathrm{P}_{14,6,6,6}\right][\mathrm{TCB}]$. The selectivity of $[\mathrm{DMIM}][\mathrm{TCB}]$ was higher than that of 
[HMIM][TCB]. Besides, the study proved that longer alkyl chains of the cation provide higher selectivity and distribution ratio of butanol.

\section{Materials and experimental setup}

In the experiments, 1-butyl-3-methylimidazolium methyl sulfate ([BMIM] $\left[\mathrm{MeSO}_{4}\right]$ ) (of 99.7\% purity) acquired from Sigma Aldrich was employed as the extracting agent. Chemical structure of the ionic liquid is shown in Figure 1. Ethanol of $99.6 \%$ purity was purchased from Stanlab. The porous hollow fiber membrane made of polypropylene, with internal and external diameters of $2 \mathrm{~mm}$ and $3 \mathrm{~mm}$ respectively, was acquired from Polymem. The membrane contactor consisted of seven hollow fiber membranes with the total external surface area of $0.086 \mathrm{~m}^{2}$.

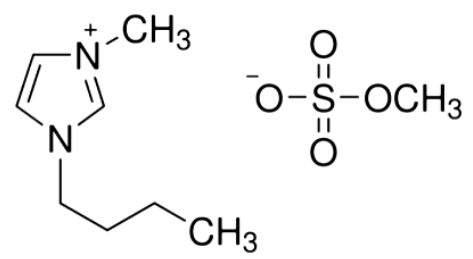

Fig. 1. Chemical structure of 1-butyl-3methylimidazolium methyl sulfate IL

The ionic liquid was selected based on the reports concerning ILs affinities for ethyl alcohol.

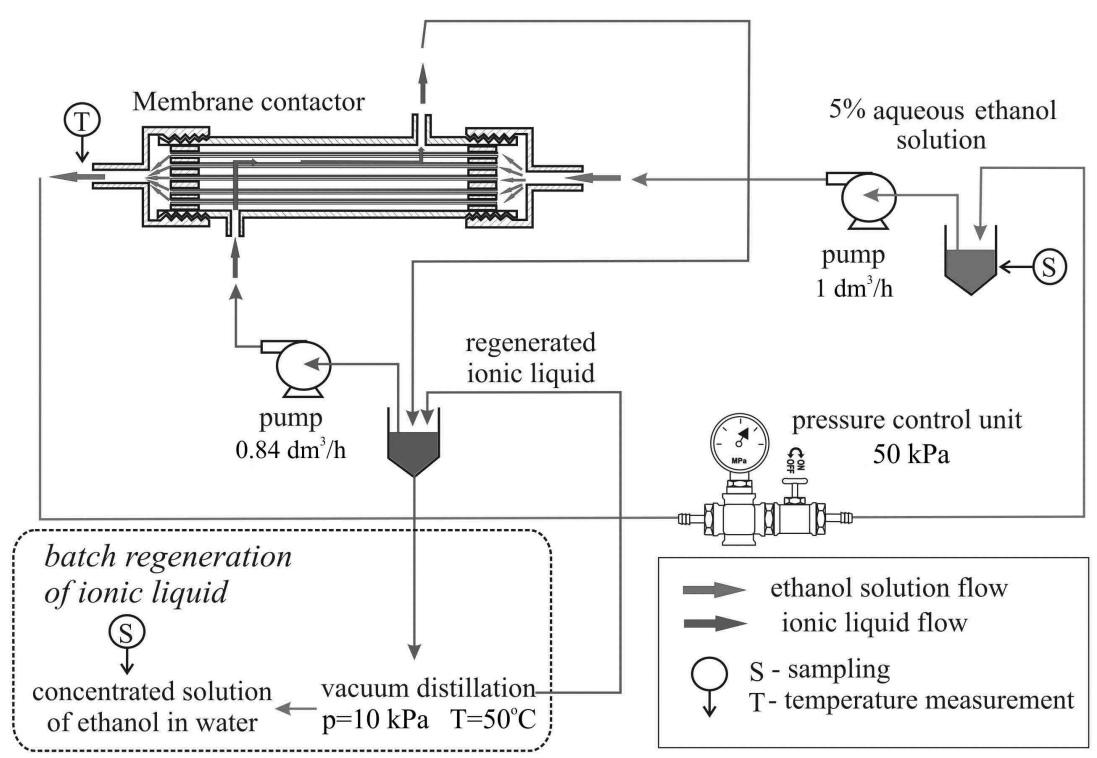

Fig. 2. Schematic diagram of the apparatus used for ethanol concentration from aqueous solutions including the hollow fiber membrane contactor and ionic liquid 
The recovery of ethanol from diluted aqueous solutions was studied using an apparatus consisting of two parts. The first part was the extraction section, ie membrane contactor with hollow fibers. The second part was used for the IL regeneration $\left(120\right.$ minutes, $50^{\circ} \mathrm{C}$ at $10 \mathrm{kPa}$ ). This stage involved evaporation of ethanol and water from the solvent for reuse in the process. The IL was regenerated using IKA RV10 evaporator and IKA HB10 heating bath. The hollow fiber membrane contactor included an external part - the casing with inlet connections, and an internal part with the hollow fiber membrane and sealing. The casing was made of $316 \mathrm{~L}$ stainless steel. Schematic drawing of the apparatus for ethanol recovery is shown in Figure 2.

The main element of the experimental setup was the membrane contactor with the polypropylene hollow fiber membrane. The experiments were carried out with various concentrations of the feed solution (1-5 wt.\%) and feed flow rates $\left(1.0,4.0\right.$ and $\left.8.0 \mathrm{dm}^{3} / \mathrm{h}\right)$. The initial amount of ethanol solution in each process was the same $(500 \mathrm{~g}) .200 \mathrm{~g}$ of 1-butyl-3-methylimidazolium methyl sulfate IL were used in each extraction process. Each experiment lasted for 1 hour.

The IL was fed to the apparatus through the shell side using a pump at $0.84 \mathrm{dm}^{3} / \mathrm{h}$, and the alcohol solution flowed in counter-current mode through the lumen side at the constant volumetric flow rate at $50 \mathrm{kPa}$. The alcohol solution was recirculated. The IL was able to dissolve alcohol better than water; therefore, alcohol concentration was observed. At the end of the process, the IL was regenerated in the evaporator. After this stage, the IL was ready for reuse in later experiments. To ensure proper measurement accuracy, each experiment was performed three times. The averaged results are presented in Table 4. Measurement errors were rated at not exceeding $3 \%$.

\section{Results and discussion}

The extraction experiments were conducted at the feed pressure of $50 \mathrm{kPa}$ to ensure a proper interfacial contact of the feed and ionic liquid. Low pressure guarantees that the membrane pores contain only vapors of the components. If the pressure is too high, the feed may flow through the pores and mix with the extracting solvent.

Another factor that influences the extraction process is the slip velocity, ie the relative movement of the feed and extractant. In the experiments, constant volumetric flow rate of the ionic liquid was assumed; therefore, the slip velocity essentially depended on the feed flow rate. As is shown by Figure 3, an increase of this flow rate slightly improves the efficiency of extraction. It should be understood that this is the effect of two simultaneous mechanisms, ie although an increase in the slip velocity shortens the contact time between the phases, it enhances the mass transfer coefficient.

The efficiency of extraction, $E$, was determined using the coefficient defined by equation (1), which is the ratio of molar concentration of ethanol in the extract $C m_{E}$ to molar concentration of ethanol in the feed $\mathrm{Cm}_{F}$ :

$$
E=\frac{C m_{E}}{C m_{F}} \cdot 100 \%
$$

Higher concentrations of ethanol in the feed resulted in lower efficiency of the extraction process. Furthermore, higher efficiencies were observed when the feed flow rate 
was growing. The relation between efficiency and ethanol molar concentration in the feed is shown in Figure 3.

Table 4

Results for various ethanol flow rates in the feed and various feed concentrations

\begin{tabular}{|c|c|c|c|c|c|}
\hline $\begin{array}{c}\text { Ethanol } \\
\text { concentration in } \\
\text { the feed [wt.\%] }\end{array}$ & $\begin{array}{c}\text { Ethanol molar } \\
\text { concentration in } \\
\text { the feed } \\
{\left[\mathrm{mol} / \mathrm{dm}^{3}\right]} \\
\end{array}$ & $\begin{array}{l}\text { Feed flow rate } \\
{\left[\mathrm{dm}^{3} / \mathbf{h}\right]}\end{array}$ & $\begin{array}{c}\text { Ethanol molar } \\
\text { concentration in } \\
\text { the extract } \\
{\left[\mathrm{mol} / \mathrm{dm}^{3}\right]}\end{array}$ & $\begin{array}{c}\text { Ethanol } \\
\text { concentration } \\
\text { in the extract } \\
\text { [wt. \%] }\end{array}$ & $\begin{array}{c}\text { Extraction } \\
\text { efficiency } \\
{[\%]}\end{array}$ \\
\hline \multirow{3}{*}{1} & \multirow{3}{*}{0.17} & 1 & 2.91 & 16.99 & 17.12 \\
\hline & & 4 & 3.43 & 20.03 & 20.18 \\
\hline & & 8 & 3.43 & 20.03 & 20.18 \\
\hline \multirow{3}{*}{2} & \multirow{3}{*}{0.34} & 1 & 2.91 & 16.99 & 8.56 \\
\hline & & 4 & 3.43 & 20.03 & 10.09 \\
\hline & & 8 & 3.77 & 22.01 & 11.09 \\
\hline \multirow{3}{*}{3} & \multirow{3}{*}{0.51} & 1 & 3.48 & 20.32 & 6.82 \\
\hline & & 4 & 3.77 & 22.01 & 7.39 \\
\hline & & 8 & 4.28 & 24.99 & 8.39 \\
\hline \multirow{3}{*}{4} & \multirow{3}{*}{0.69} & 1 & 3.77 & 22.01 & 5.46 \\
\hline & & 4 & 4.28 & 24.99 & 6.20 \\
\hline & & 8 & 4.80 & 28.03 & 6.96 \\
\hline \multirow{3}{*}{5} & \multirow{3}{*}{0.86} & 1 & 4.28 & 24.99 & 4.98 \\
\hline & & 4 & 4.62 & 26.98 & 5.37 \\
\hline & & 8 & 5.14 & 30.01 & 5.98 \\
\hline
\end{tabular}

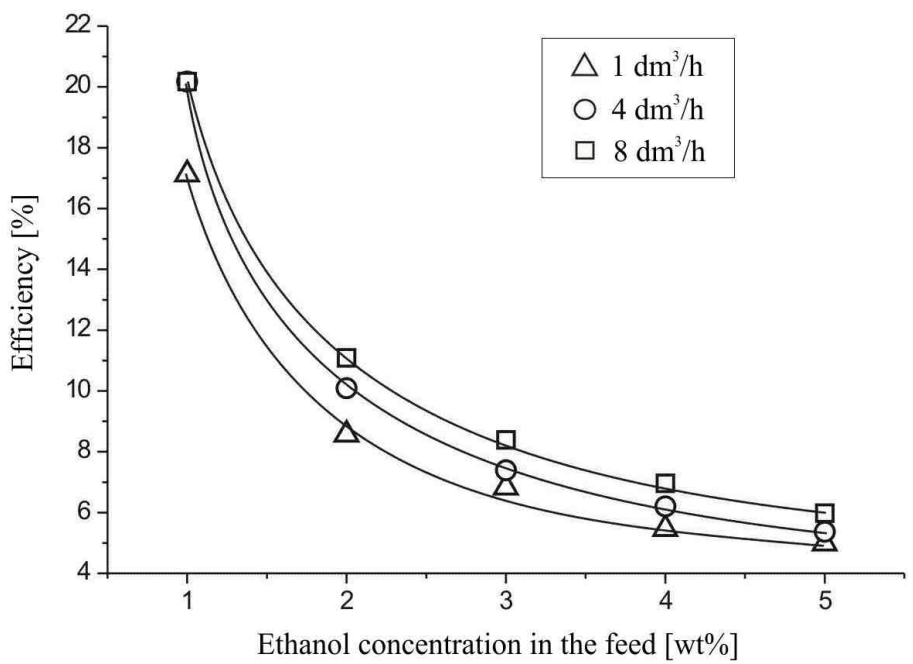

Fig. 3. Ethanol concentration in the feed vs. extraction efficiency at various feed flow rates

When the initial mass fraction of ethanol in the feed was equal to 1 wt.\%, approximately 19-fold average concentration in the extract in relation to the feed solution was achieved; however, at higher mass fractions the degree of ethanol concentration was dropping (to about 5.5-fold concentration at $5 \mathrm{wt} . \%$ of ethanol in the feed). 


\section{Conclusions}

The results presented in this paper may be summarized as follows:

1. The efficiency of ethanol recovery from diluted aqueous solutions using hollow fiber membrane contactor and ionic liquids can be considered satisfactory.

2. The measured ethanol concentrations in the extract ranged from 16.99 to $30.01 \mathrm{wt} . \%$.

3. The results show that the membrane extraction process using the hollow fiber membrane contactor and $[\mathrm{BMIM}]\left[\mathrm{MeSO}_{4}\right]$ can be successfully used to recover ethanol from aqueous solutions.

\section{Symbols}

IL - ionic liquid

SLM - supported liquid membrane

SILM - supported ionic liquid membrane

$E$ - efficiency of extraction process [\%]

$C m_{F}$ - molar concentration of ethanol in the feed $\left[\mathrm{mol} / \mathrm{dm}^{3}\right]$

$C m_{E}$ - molar concentration of ethanol in the extract $\left[\mathrm{mol} / \mathrm{dm}^{3}\right]$

[EMIM] $\left[\mathrm{EtSO}_{4}\right]$ - 1-ethyl-3-methylimidazolium ethyl sulfate

[BMIM] $\left[\mathrm{BF}_{4}\right]$ - 1-butyl-3-methylimidazolium tetrafluoroborate

[BMIM] $\left[\mathrm{MeSO}_{4}\right]$ - 1-butyl-3-methylimidazolium methyl sulfate

[MMIM] $\left[\mathrm{MeSO}_{4}\right]$ - 1,3-dimethylimidazolium methyl sulfate

[HMIM][TCB] - 1-hexyl-3-methylimidazolium tetracyanoborate

[DMIM][TCB] - trihexyltetradecylphosphonium tetracyanoborate

$\left[\mathrm{P}_{14,6,6,6}\right][\mathrm{TCB}]$ - trihexyl(tetradecyl)phosphonium tetracyanoborate

\section{References}

[1] Yang M, Cussler E. Designing hollow-fiber contactors. AIChE J. 2004;32:1910-1916. DOI: 10.1002/aic.690321117.

[2] Gabelman A, Hwang S. Hollow fiber membrane contactors. J Membr Sci. 1999;159:61-106. DOI: 10.1016/S0376-7388(99)00040-X.

[3] Kreulen H, Versteeg GF, Smolders CA, Swaaij WPM van. Microporous hollow fibre membrane modules as gas-liquid, Part 1. Physical mass transfer in highly viscous liquids. J Membr Sci. 1993;78:197-216. DOI: 10.1016/0376-7388(93)80001-E.

[4] Drioli E., Curcio E. Membrane engineering for process intensification: a perspective. J Chem Technol Biotechnol B. 2007;82:223-227. DOI: 10.1002/jctb.1650.

[5] Wickramansinghe SR, Semmens MJ, Cussler EL. Mass transfer in various hollow fiber geometries. J Membr Sci. 1992;69:235-250. DOI: 10.1016/0376-7388(92)80042-I.

[6] Mansourizadeh A, Ismail A. Hollow fiber gas-liquid membrane contactors for acid gas capture: A review. J Hazard Mater. 2009;171:38-5. DOI: 10.1016/j.jhazmat.2009.06.026.

[7] De Montigny D, Tontiwachwuthikul P. Comparing the absorption performance of packed columns and membrane contactors. Ind Eng Chem Res. 2005;44:5726-5732. DOI: 10.1021/ie040264k.

[8] Simons K, Nijmeijer K, Wessling M. Gas-liquid membrane contactors for $\mathrm{CO}_{2}$ removal. J Membr Sci. 2009;340:214-220. DOI: 10.1016/j.memsci.2009.05.035.

[9] Drioli E, Curcio E. State of the art and recent progresses in membrane contactors. Chem Eng Res Design. 2005;83:23-23. DOI: 10.1205/cherd.04203.

[10] Drioli E, Curcio E. Membrane distillation and related operations - A review. Sep Purif Rev B. 2005;34:35-86. DOI:10.1081/SPM-200054951.

[11] Drioli E, Criscuoli A, Curcio E. Membrane Contactors: Fundamentals, Applications and Potentialities. Membr Sci Technol Ser. Volume 11, Chapter 11, Amsterdam: Elsevier B.V.; 2006. 
[12] Noble R, Gin D. Perspective on ionic liquids and ionic liquid membranes J Membr Sci. 2011;369:1-4. DOI: 10.1016/j.memsci.2010.11.075.

[13] Dhanalakshmi J, Sai PST, Balakrishnan AR. Study of ionic liquids as entrainers for the separation of methyl acetate-methanol and ethyl acetate-ethanol systems using the COSMO-RS model. Ind Eng Chem Res. 2013;52:16396-16405. DOI: 10.1021/ie402854k.

[14] Han D, Ho Row KH. Recent applications of ionic liquids in separation technology. Molecules. 2010;15:2405-2426. DOI:10.3390/molecules 15042405 .

[15] Pereiro AB, Araujo JMM, Esperanca JMSS, Marrucho IM, Rebelo LPN. Ionic liquids in separations of azeotropic systems - a review. J Chem Thermodyn. 2012;46:2-28. DOI: 10.1016/j.jct.2011.05.026.

[16] Meindersma GW, Quijada-Maldonado E, Aelmans TAM, Hernandez JPG, de Haan AB. Ionic liquids in extractive distillation of ethanol/water: from laboratory to pilot plant. Ionic Liquids: Science and Applications. ACS Symposium Series. 2012;1117:239-257. DOI: 10.1021/bk-2012-1117.ch011.

[17] Albo J, Luis P, Irabien A. Absorption of coal combustion flue gases in ionic liquids using different membrane contactors. Desalin Water Treat. 2011;27:54-59. DOI: 10/5004/dwt.2011.2050.

[18] Luis P, Garea A, Irabien A. Zero solvent emission process for sulfur dioxide recovery using a membrane contactor and ionic liquids. J Membr Sci. 2009;330:80-89. DOI: 10.1016/j.memsci.2008.12.046.

[19] Won J, Kim DB, Kang YS, Choi DK, Kim HS, Kim CK et al. An ab initio study of ionic liquid silver complexes as carriers in facilitated olefin transport membranes. J Membr Sci. 2005;260:37-44. DOI: 10.1016/j.memsci.2005.03.040.

[20] Ortiz A, Gorri D, Irabien A, Ortiz I. Separation of propylene/propane mixtures using Ag A $^{+}$TIL solutions. Evaluation and comparison of the performance of gas-liquid contactors. J Membr Sci. 2010;360:130-141. DOI: 10.1016/j.memsci.2010.05.013.

[21] Pereiro A, Rodriguez A. Azeotrope-breaking using [BMIM] $\left[\mathrm{MeSO}_{4}\right]$ ionic liquid in an extraction column. Separat Purif Technol. 2008;62:733-738. DOI: 10.1016/j.seppur.2008.03.015.

[22] Pereiro A, Rodriguez A. Separation of ethanol-heptane azeotropic mixtures by solvent extraction with an ionic liquid. Ind Eng Chem Res. 2009;48:1579-1585. DOI: 10.1021/ie8011769.

[23] Calvar N, Gonzalez B, Gomez E, Dominguez A. Vapor-liquid equilibria for the ternary system ethanol + water + 1-butyl-3-methylimidazolium methyl sulfate and the corresponding binary systems at $101.3 \mathrm{kPa}$. J Chem Eng Data. 2009;54:1004-1008. DOI: 10.1021/je800828y.

[24] Kaminski W, Tomczak E, Gorak A. Biobutanol - production and purification methods. Ecol Chem Eng S. 2011;18:31-37.

[25] Kubiczek A, Kaminski W. Ionic liquids for the extraction of n-butanol from aqueous solutions. Ecol Chem Eng A. 2013;20:77-87. DOI: 10.2428/ecea.2013.20(01)009.

[26] Lee SY, Park JH, Jang SH, Nielsen LK, Kim J, Jung KS. Fermentative butanol production by Clostridia. Biotechnol Bioeng. 2008;101:209-228. DOI: 10.1002/bit.22003.

[27] Fadeev AG, Meagher MM. Opportunities for ionic liquids in recovery of biofuels. Chem Commun. 2001;3:295-296. DOI: 10.1039/b006102f.

[28] Domanska U, Krolikowski M. Extraction of butan-1-ol from water with ionic liquids at $\mathrm{T}=308.15 \mathrm{~K}$. J Chem Thermodyn. 2012;53:108-113. DOI: 10.1016/j.jct.2012.04.017. 


\title{
ODZYSKIWANIE ETANOLU Z NISKOSTEŻ̇ONYCH ROZTWORÓW WODNYCH Z UŻYCIEM KONTAKTORÓW MEMBRANOWYCH I CIECZY JONOWEJ
}

\author{
Wydział Inżynierii Procesowej i Ochrony Środowiska, Politechnika Łódzka
}

\begin{abstract}
Abstrakt: Odzyskiwanie alkoholu z rozcieńczonych roztworów wodnych jest procesem wysoko energochłonnym. W celu obniżenia kosztów do zatężania rozcieńczonych roztworów alkoholi wykorzystuje się procesy membranowe, między innymi ekstrakcję membranową. W pracy przedstawiono wyniki badań procesu zatężania rozcieńczonych wodnych roztworów etanolu w kontaktorze membranowym z zastosowaniem cieczy jonowej. W przeprowadzonych eksperymentach wykorzystano kontaktor membranowy z mikroporowatymi membranami kapilarnymi stanowiącymi barierę między roztworem surowym a ekstrahentem i jednocześnie zapewniającymi dużą powierzchnię wymiany masy. W procesie jako ekstrahenta użyto cieczy jonowej wykazującej selektywność w stosunku do etanolu. Omówiono wyniki badań procesu zatężania roztworów etanolu o stężeniach 1 do 5\% masowych i natężeniach przepływu nadawy zmienianych w zakresie od $1 \mathrm{do} 8 \mathrm{dm}^{3} / \mathrm{h}$.
\end{abstract}

Słowa kluczowe: kontaktor membranowy, ciecz jonowa, ekstrakcja membranowa 